\title{
REVISTAMARACANAN
}

\section{Política, história e instituições republicanas no primeiro Quattrocento: a Florença de Leonardo Bruni}

\section{Politics, history and republican institutions in the first Quattrocento: Florence by Leonardo Bruni}

Fabrina Magalhães Pinto*

Universidade Federal Fluminense

Campos dos Goytacazes, Rio de Janeiro, Brasil

Recebido em: 04 fev. 2020.

Aprovado em: 07 abr. 2020.

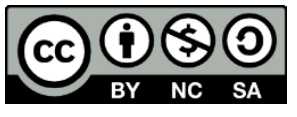

\footnotetext{
* Professora Adjunta de História da Universidade Federal Fluminense, Polo Universitário de Campos dos Goytacazes. Doutora e Mestre em História Social da Cultura pela Pontifícia Universidade Católica do Rio de Janeiro; graduada em História pela Universidade Federal Fluminense. Realizou estágio de pósdoutorado em Filosofia na Pontifícia Universidade Católica do Rio de Janeiro e na Universidade Federal de Minas Gerais. (fabrinamagalhaes@gmail.com)

ORCID iD: https://orcid.org/0000-0001-5088-9125

CV Lattes: http://lattes.cnpq.br/0342630078480911
} 


\section{Resumo}

Leonardo Bruni (1370-1444), chanceler e historiador, é autor de um dos principais elogios da cidade de Florença deste período. Ao escrever a Laudatio florentinae urbis (1403-1404), o humanista descreve Florença e seu governo como uma cidade bem ordenada, bela, salubre, livre e participativa. O artigo analisa este texto não apenas como peça retórica, mas ressalta os ideais republicanos de liberdade, autogoverno e cidadania. De um ponto de vista institucional, a Laudatio oferece as bases do governo misto, que se tornaria um aspecto central do republicanismo renascentista. Dos antigos, Bruni retira a ideia de divisão dos poderes a partir da clássica tríade monarquia, aristocracia e democracia, com a separação de funções em cada uma destas formas puras. Bruni ressalta que ambos os aspectos da Antiguidade podem ser encontrados nas instituições florentinas de seu tempo, de tal modo que ele observa no fato histórico a realização de uma teoria política antiga, complementando, pois, a idealização da cidade.

Palavras-chave: Leonardo Bruni. Cidade Ideal. Republicanismo Renascentista. Governo Misto.

\section{Astract}

Leonardo Bruni (1370-1444), chancellor and historian, is the author of one of the main praises of the city of Florence of this period. In writing to Laudatio florentinae urbis (1403-1404), the humanist describes Florence and its government as a well-ordered, beautiful, wholesome, free and participatory city. The article analyzes this text not only as a rhetorical piece, but highlights the republican ideals of freedom, self-government and citizenship. From an institutional point of view, Laudatio offers the foundations of mixed government, which would become a central aspect of Renaissance republicanism. From the ancients, Bruni removes the idea of the division of powers from the classic triad monarchy, aristocracy and democracy, with the separation of functions in each of these pure forms. Bruni points out that both aspects of antiquity can be found in the Florentine institutions of his time, in such a way that he observes in the historical fact the realization of an ancient political theory complementing, therefore, the ideialization of the city.

Keywords: Leonardo Bruni. Ideal City. Renaissance Republicanism. Mixed Government. 


\section{A construção da cidade ideal em Florença}

Florença, juntamente com outras cidades italianas, se torna uma república ainda no século XII. Lutando contra potentes adversários como o Sacro Império Romano Germânico, num primeiro momento, e a Igreja, posteriormente, a república florentina se mantém livre até mesmo quando enfrenta militarmente o seu mais poderoso rival: o ducado de Milão, em inícios do século $X V{ }^{1}$ Desse modo, tem-se nesse intervalo a construção paulatina de um ideal de cidade: seja no plano arquitetônico, seja no plano político e em suas instituições.

Em uma das suas tantas definições possíveis, a cidade ideal se refere a um tipo de assentamento urbano (projetado, ou apenas imaginado,) cujo desenho urbano reflete, de acordo com um esquema predominantemente geométrico, critérios abstratos e princípios de racionalidade e funcionalidade altamente desenvolvidos que podem acompanhar ou não critérios filosóficos. Pode-se dizer ainda, de forma geral, que o tema da cidade ideal cobriu toda a história da humanidade urbanizada, desde a Antiguidade, mas que este retorna com força particular no Renascimento italiano, quando a cidade, sobretudo após a queda de Roma e a superação do interlúdio feudal, novamente assumiu o papel central de um lugar privilegiado para a ação do homem. A partir do século XV, de fato, a experiência teórica e o debate sobre a "cidade ideal" se tornam intensos o suficiente para tornar esse tema, mesmo na ausência de realizações práticas reais, uma das grandes junções inspiradoras em que a reflexão sobre a arte, arquitetura, filosofia e urbanismo renascentista encontrariam-se reunidos em perfeita ordem.

Em Florença esse processo não se deu apenas de forma ideal ou abstrata, mas foi construída fisicamente, sobretudo ao longo dos séculos XII e XV, quando foi possível evidenciar uma preocupação com os aspectos arquitetônicos e urbanísticos; ${ }^{2}$ como a construção de prédios públicos e o projeto de expansão da catedral de Santa Maria del Fiore (que passou a ter 153 metros de comprimento, 90 metros de largura em seu ponto mais amplo, e 86,7 metros de altura). Foi previsto ainda a construção de uma grande cúpula que se tornaria o novo símbolo de Florença, sendo sua extensão tão grandiosa (41 metros) que a solução para a sua cobertura só viria um século mais tarde, em 1418, com o próprio Brunelleschi. O Duomo, e seu grandioso projeto arquitetônico, o Batistério e Campanário de Giotto, o Hospital dos Inocentes, o Palazzo Vechio, e várias outras construções públicas já indicavam a construção de uma cidade ideal, e uma cidade livre. ${ }^{3}$ Nesse sentido, na medida

\footnotetext{
${ }^{1}$ BRUCKER, Gene. Dal Comune alla Signoria. La vita publica a Firenze nel primo Rinascimento. Bologna: [s.n.], 1981; SKINNER, Quentin. Fundações do Pensamento político Moderno. São Paulo: Companhia das Letras, 1996; NAJEMY, John. Storia di Firenze, 1200-1575. Turim: Einaudi, 2014.

${ }^{2}$ Esta hipótese foi desenvolvida em: PINTO, Fabrina M. A cidade ideal de Leonardo Bruni. Morus - Utopia e Renascimento, v. 10, p. 367-388, 2015, p. 57-77.

3 Para termos uma ideia das inúmeras construções do período, citamos aqui, além do projeto e concurso para a construção da Igreja Santa Maria del Fiore, o concurso para a elaboração das portas em bronze do Batistério de São João, em que concorreram Lorenzo Ghiberti, Filippo Brunelleschi e Donatello. O
} 
em que avançava a república, avançava também o desejo pela criação de um modelo urbanístico e arquitetônico para a cidade, capaz de suplantar todas as demais rivais em opulência e magnificência. Estariam associdados diretamente, portanto, as ambições políticas, republicanas e expansionistas com a constituição de uma imagem ideal de uma cidade, onde imperaria a justiça, a racionalidade e a liberdade. E tal modelo tão elevado só poderia ser pensando e construído em uma república como a florentina, herdeira de Roma e dos princípios de virtude dos antigos.

São de grande importância os tratados escritos sobre as cidades ideais, basta pensarmos em Alberti, Filarete e Leonardo. Do mesmo modo, podemos observar a preocupação com as representações da cidade também na arte, pois, temos já, desde o século XIV, diversas imagens sobre as vilas ideais. Basta olharmos para Simone Martini ( $A$ vitória do condottieri Giudoriccio da Fogliano, de 1328); Botticelli (O Suicídio de Lucrécia, 1498); Perspectiva da cidade ideal, atribuída a Piero della Francesca, de 1470; Perugino ( $A$ entrega das chaves a São Pedro, de 1482); Vittore Carpaccio (São Jorge em luta contra o dragão, 1502-1507). Seguem como exemplos duas dessas belíssimas representações:

Figura 1 - A Cidade ideal de Piero della Francesca.

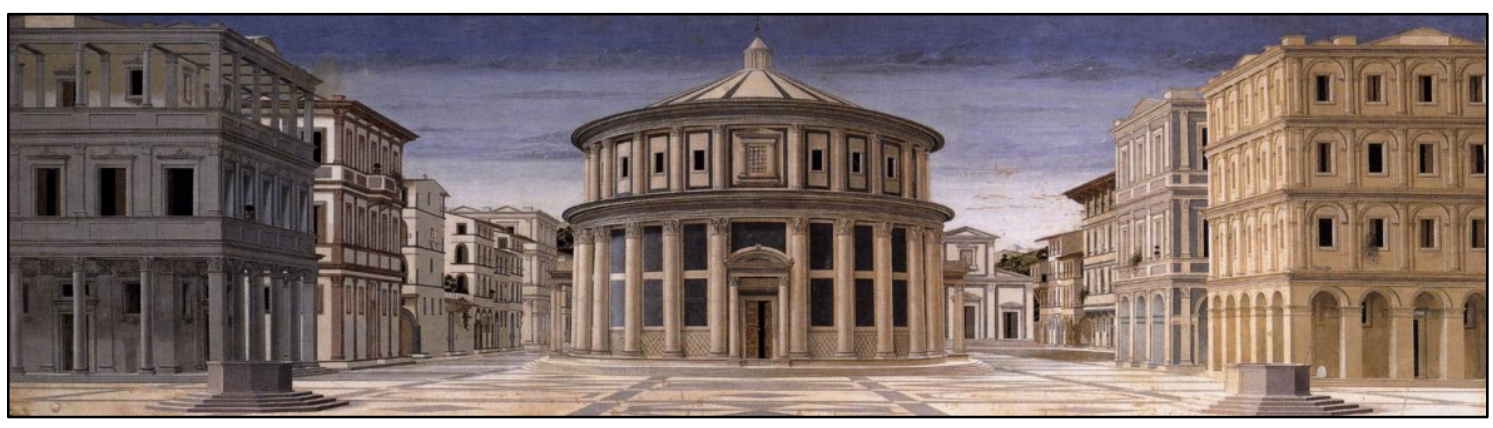

Fonte: DELLA FRANCESCA, Piero. Cittá ideale. [circa 1470]. Pannello, olio su tavola, 67,7 x 239,4 cm. (Galleria Nazionale delle Marche, Urbino, Itália).

Figura 2 - Cidade ideal de um pintor desconhecido.

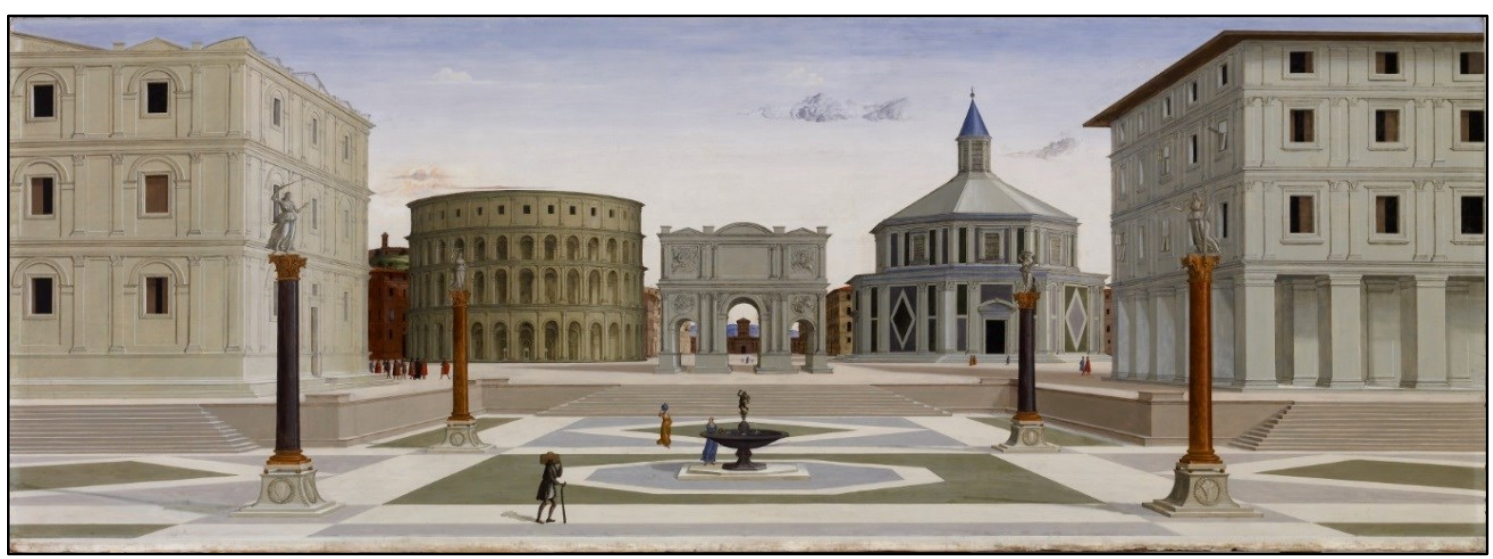

Fonte: Cittá ideale. [circa 1480]. Pannello, olio su tavola, 77,4 × $220 \mathrm{~cm}$. (The Walters Art Museum, Baltimore - MD, United States).

resultado destes concursos geraram obras que se transformaram ao longo dos séculos nos grandes símbolos da cidade até hoje. 
Não há dúvidas de que em ambas as pinturas existe uma preocupação no uso das leis da perspectiva e proporções que aparece também nos pintores citados acima. Contudo, há de se destacar a obra de Pierro dela Francesca, que escreveu os tratados De Prospectiva pingendi e De Corporibus regularibus, em que analisou os fundamentos teóricos e científicos de sua cultura pictórica. É a partir de seus desenhos em De Prospectiva que a construção perspectiva do painel chamado Ideal City nasce. Esta pintura é tão intimamente ligada aos escritos teóricos de Piero que ela deve ter sido pintada por um colaborador muito próximo seu. Contudo, se respeitarmos as datações das obras (sejam elas escritas ou não), podemos citar o Elogio da cidade de Florença (Laudatio Florentinae urbis, escrito entre 1403-1404) por Leonardo Bruni, como parte dos primeiros escritos sobre as cidades ideais; ${ }^{4}$ e adiantaríamos pelo menos meio século se a compararmos com outros trabalhos de meados e fim do Quattrocento, por exemplo. ${ }^{5}$ Diz o humanista e chanceler da república florentina sobre as construções da cidade em sua Laudatio:

O que há em todo orbe terrestre mais esplêndido ou tão magnífico que se possa comparar com seus edifícios? Envergonho-me das outras cidades toda vez que me vem à mente tal comparação. Isso porque elas possuem em geral apenas uma ou duas ruas bem construídas, nas outras todas a ausência de bela constituição é tal que elas enrubescem grandemente de vergonha ao serem vistas por estrangeiros. (Bruni, Laudatio, $\S 10){ }^{6}$

\footnotetext{
${ }^{4}$ Leonardo Bruni nasceu em Arezzo, por volta de 1370. Durante os anos de 1390 se tornou discípulo do chanceler florentino Coluccio Salutati, começando, em inícios do século XV, uma carreira marcada pela redação de trabalhos como a Laudatio Florentinae urbis, que, como vem sendo demonstrado pela literatura especializada (H. Baron, E. Garin, P. Viti, C. Vasoli, J. Hankins, B. Pradelle, entre tantos outros) foram fundamentais para o pensamento político e cultural do Quattrocento italiano. Esse período também é marcado por suas primeiras traduções - como a Política de Aristóteles - e por sua ascensão ao posto de secretário pontificial em 1405. Lançando mão de um amplo conhecimento da cultura clássica, bem como de conceitos e formulações teóricas a respeito da política e da República, seus textos tiveram grande sucesso dentro e fora da península itálica, e representam o processo de racionalização e secularização da política em inícios da modernidade. Bruni tornou-se chanceler florentino por um primeiro momento, entre 1406 e 1411 e, depois, de 1427 a 1444 - ano de sua morte. Retornando a Florença em 1415, iniciou a redação da sua célebre Historiae Florentini Populi, talvez a sua obra mais importante e que o acompanha em seu túmulo na Igreja de Santa Croce, em Florença. Para uma biografia completa do humanista, bem como a relação de todas as suas obras (Dialogi, De Militia, Oratio in funere Iohannis Strozzae, Difesa contro i reprensori del popolo di Firenze, entre tantas outras). Cf.: VASOLI, Cesare. Bruni Leonardo. In: Dizionario biografico degli italiani. Tomo 14. Rome: Istituto dela Enciclopedia italiana, 1972; HANKINS, James. Coluccio Salutati e Leonardo Bruni. In: CILIBERTO, M. (org.). Enciclopedia Italiana. Ottava appendice. Il contributo italiano alla storia del pensiero. Roma: Filosofia, 2012.

${ }^{5}$ GARIN, Eugênio. La citè idéale de la Renaissance Italienne. In: Les utopies à la Renaissance. Bruxelles: Presses Universitaires de Bruxelles, 1963, p. 13-16; PINTO, Fabrina M. A cidade ideal de... Op. cit., p. 57-77.

${ }^{6}$ Podemos encontrar as seguintes traduções dos textos de Bruni: BARON, H. From Petrarch to Leonardo Bruni: Studies in Humanistic and Political Literature. Chicago: University of Chicago Press, 1968, p. 232263; KOHL, B. G; WITT, R. G. The Earthly Republic: Italian Humanists on Government and Society. Philadelphia: University of Pennsylvania Press, 1978, p. 135-175 (tradução inglesa); GRIFFITHS, G; Hankins, J.; THOMPSON, D. The Humanism of Leonardo Bruni. Binghamton; New York: Center for Medieval and Early Renaissance Studies, 1987, p. 116-121 (a parte IV apenas foi traduzida); VITI, Paolo. Opere letterarie e politiche di Leonardo Bruni. Torino: Unione Tipografico-Editrice Torinese, 1996 (tradução italiana); BRUNI, Leonardo. Laudatio Florentinae Urbis. In: Histoire, Éloquence et Poésie à Florence au début du Quattrocento. Textes choisis, édites et traduits par Laurence Bernard-Pradelle. Paris: Honoré Champion, 2008, p. 205-301 (edição bilíngue latim-francês); PINTO, Fabrina M. O Elogio da cidade de Florença (Laudatio Florentinae Urbis), de Leonardo Bruni. Morus - Utopia e Renascimento, v.
} 
Serei eu um tolo por ficar enumerando tudo isso? Ainda que eu tivesse cem línguas, cem bocas e uma voz de ferro, não poderia mostrar toda a magnificência, as belas construções, os tesouros, o luxo e o brilho de Florença. (Bruni, Laudatio, § 12).

Florença é tão bem fornida de grandeza e esplendor que ela supera de longe não apenas as cidades da Itália, mas as de todas as províncias mais distantes. Essa abundância de coisas bonitas, que sempre oferece rico material para descrever a cidade, me tomou com tal intensidade e violência que não me deu nenhuma chance de descansar. Talvez, por isso, eu tenha elaborado meu discurso tão efusivamente na tentativa de descrever tudo que tenha omitido justamente os primeiros e mais importantes. (Bruni, Laudatio, § 28-29). ${ }^{7}$

Para o historiador, Florença era a cidade ideal tanto por sua posição geográfica, sua forma de governo e prosperidade econômica, quanto pelo conjunto de suas edificações, centralidade de suas formas e por sua racionalidade sem precedentes; sobretudo se a compararmos com as cidades medievais da época. Assim, afirma claramente que nada é desordenado, inconveniente, sem razão ou sem fundamento na cidade, posto que tudo possui seu lugar. Mas a originalidade do autor não deve ser buscada apenas em suas teorias urbanas, pois também na política esta obra se destaca, tendo em vista que o elogio à cidade se desenvolve ao mesmo tempo com o elogio dos cidadãos, que superam em virtù todos os outros homens da mesma forma que Florença supera todas as outras cidades. Assim, suas descrições são acompanhadas de uma análise detalhada tanto da fundação da cidade quanto da constituição de Florença, erigida, segundo ele, nos princípios de ius e libertas. ${ }^{8}$

Como afirma Eugenio Garin, algumas das principais obras que trataram das cidades ideais são escritas a partir da segunda metade do século XV: como o L'architetura (De $R e$ Aedificatoria), de Leon Battista Alberti, publicado em 1486, o Trattato di Architettura, de Filarete, (escrito entre 1461 e 1464), e o Codex Atlanticus, de Leonardo (escrito entre 14781519). ${ }^{9}$ É suficiente lembrar a representação de Leonardo da Vinci sobre a cidade de Milão. Em seu Codex Atlanticus, aconselha Ludovico, o Mouro, a embelezar a cidade, preocupando-se com a higiene, o armanezamento de água, a distribuição da população e a criação de bairros mais organizados. Deste modo, concordamos com o autor quando afirma que o esboço de Leonardo, longe de representar um plano puramente imaginário, está ligado já às aspirações

11, n. 2, p. 243-335, 2016 (tradução latim-português). Todas as referências e citações do texto serão retiradas desta versão.

Sobre a fortuna e a influência da Laudatio, ver: BALDASSARI, S. U. Introduzione. In: BRUNI, Leonardo. Laudatio Florentinae Urbis. Edizione di Stefano U. Baldassari. Firenze: Sismel, 2000, p. XXIIIXVII. Segundo Clémence Revest, a Laudatio foi imitada por vários humanistas no curso do século XV. Em 1436, o humanista milanês Pier Candido Vegerio responde o Elogio, imitando o discurso epidíctico de Bruni, com o De laudibus Mediolanensium Urbis Panegyricus. Da mesma forma, Enea Silvio Piccolomini fora inspirado pela Laudatio em carta de 1438, onde ele coloca Bâle no centro do mundo e afirma ser lá, em vez de Florença, o melhor lugar para a realização do concílio que irá definir os termos da liga antemilanesa. REVEST, Clémence. Les enjeux de la transmission aux origines de l'humanisme: I'exemple de I'Éloge de la ville de Florence de Leonardo Bruni. Questes, 11, p. 7-16, 2007, p. 12.

7 Bruni menciona a existência de elogios anteriores à cidade, mas, por outro lado, destaca tudo aquilo que não foi mencionado por eles, sem nem mesmo citar a Invectiva, de seu mestre Coluccio Salutati, escrita pouco antes. Para a edição latina litaliana do texto de Salutati, Invectiva contra Antonio Loschi de Vicenza, ver: GARIN, Eugênio (ed.). Prosatori Latini del Quattrocento. Torino: Einaudi, 1976, p. 8-37. Para o texto traduzido para o português, ver: BIGNOTTO, N. Origens do Republicanismo Moderno. Belo Horizonte: Ed. UFMG, 2001, p. 239-253.

${ }^{8}$ RUBINSTEIN, N. Florentine libertas. Rinascimento, s. II, p. 3-26, 1986.

${ }^{9}$ GARIN, Eugênio. La citè idéale de... Op. cit., p. 15. 
reais das cidades-estado italianas, e ao desejo de que Milão se tornasse também um modelo urbanístico na Itália. As cidades ideais vinculam-se a um projeto de reformas das cidades reais. Seu espaço construtivo não é equidistante da cidade real. Como reitera Edmilson M. Rodrigues:

As cidades ideais são imaginadas a partir da dinâmica interna das cidades reais,
não necessitando de um elemento externo para adquirir sentido e ganharem
forma. Por isso, sua representação imagética tende a associá-las à cultura
aristocrática, ao refinamento nobre e à arte no sentido de sua força estética.
[...] Os critérios de ordem das cidades ideais têm uma dinâmica assegurada pela
geometrização de sua imagem, que é, ao mesmo tempo, o limite de sua
característica ideal e também sua fronteira. As cidades utópicas, ao contrário,
constituem-se a partir de um espelho externo para depois voltarem-se para
dentro das cidades reais, precisam de um espaço constituído como "alhures" ou
"lugar nenhum" para existirem. Como já são produções da segunda fase do
humanismo, posterior a Maquiavel, as cidades utópicas expressam valores éticos
e morais, associando-os ao lugar geográfico, quase todas tendo como elemento
comum estarem separadas do mundo real pelo braço de mar ou por um rio,
adquirindo a feição de uma "ilha" isolada. Por isso, são mais difíceis de serem
construídas no imaginário e possuem um ordenamento físico muito mais
detalhado. ${ }^{10}$

Já as teorizações sobre as cidades utópicas - como a Utopia, de Thomas Morus, por exemplo - são ainda posteriores, e tratam da construção racional de um não lugar, ou de um lugar no futuro.

É assim, ressalta Garin, que os tratados políticos se tornaram também tratados de arquitetura e urbanismo, acentuando a exigência pela racionalização da cidade, seja sob o plano administrativo, ou sob o arquitetônico. ${ }^{11}$ Não é difícil encontrar nos textos florentinos de fins do século XIV e início do XV, um paralelo entre as instituições da res publica e seus edifícios, e é justamente isso que faz de Florença um tipo ideal de cidade. O palácio da Senhoria e o Duomo se tornaram mais que símbolos da república, mas expressões da sua força e riqueza. A cidade deveria se transformar na medida exata que os homens avançassem politicamente. $\mathrm{E}$, nesse sentido, Florença buscou harmonizar os avanços políticos com as preocupações urbanísticas. Homens tão valorosos - protetores da república contra os mais cruéis adversários, e legítimos defensores da liberdade não apenas da cidade, mas de toda a península - deveriam habitar a mais plena das cidades. Assim, da mesma forma que confluíam para a cidade artistas, arquitetos e humanistas, a própria comuna se empenhou em fazer de Florença a maior entre as repúblicas italianas.

Por ser a Laudatio, um elogio que faz parte do gênero epidítico (que pode, portanto, omitir e mesmo amplificar certos fatos) esse texto sofrera inúmeras críticas de analistas recentes por aumentar demais as qualidade de Florença e omitir alguns dados históricos importantes (como o real motivo de Florença ter vencido Milão em batalha, que deveria ser atribuído não à força militar florentina, mas à própria ação da Fortuna que faz com que Gean-

${ }^{10}$ RODRIGUES, Antônio Edmilson Martins. Das possibilidades de cidades utópicas. Morus - Utopia e Renascimento, n. 6, 2009, p. 373.

${ }_{11}$ GARIN, Eugênio. La citè idéale de... Op. cit., p. 17. 
Galeazzo Visconti fosse morto em batalha). ${ }^{12}$ Mas, o que parece ao leitor um elogio desprentensioso de Florença ou até mesmo um texto escrito, como indicam alguns autores, apenas para que ele conseguisse uma maior inserção nos quadros políticos da cidade de Florença, nos traz uma série de outros elementos que estão imersos na segunda e terceira partes do Elogio. ${ }^{13}$ A cidade ideal bruniana deve ter - acima de tudo - liberdade, que é assegurada historicamente pela fundação realizada ainda no período republicano de Roma. A cidade ideal deve ser filantrópica e, por fim, deve ter instituições que garantam a participação popular e a igualdade entre os cidadãos. Passaremos rapidamente pelos dois primeiros pontos para nos determos com mais vagar no último: a defesa das instituições florentinas.

\section{Liberdade e fundação}

Rubinstein destacou na Laudatio a fundação como um elemento central e estruturante da obra, pois, logo após os elogios (à arquitetura, salubridade, beleza e qualidade dos cidadãos florentinos) Bruni passa ao tratamento desta questão declarando que Florença é autossuficiente e tem o direito de conquistar outras cidades, pois foi fundada pelos romanos durante o período republicano e mantém, tal qual sua predecessora, seu fervoroso ardor pela defesa das instituições e manutenção da liberdade. Segundo este autor, é clara a defesa bruniana de uma ideologia imperial, bem como da expansão territorial. ${ }^{14}$ Bruni se descolaria, portanto, do quadro jurídico-político no qual se move a Florença do chanceler Coluccio Salutati (1331-1406), em sua Invenctiva contra Antonio Loschi (1403), em que a maior preocupação é

\footnotetext{
12 HANKINS, James. The 'Baron Thesis' after Forty Years and Some Recent Studies of Leonardo Bruni. Journal of the History of Ideas, v. 56, n. 2, p. 309-338, 1995. Para James Hankins, a Laudatio teria apenas a intenção de obter o aplauso, a persuasão, diferentemente da oratória judiciaria ou deliberativa que, segundo a teoria antiga, estaria destinada a busca da verdade. Esta questão parece esvaziar-se de sentido quando lembramos que a Laudatio é um exemplo de oratória epidítica, onde se pode louvar ou vilipendiar qualquer coisa; e, inclusive, omitir ou ressaltar dados históricos. É o gênero mais livre de oratória, em que as preocupações são imediatas, pois se vincula ao presente. No caso de Bruni são imediatas porque se tratam de escolhas políticas que devem ser feitas no presente, no ato das deliberações políticas florentinas. Afastando-se na busca pela verdade teórica, ardentemente almejada pelo filósofo, o orador, abrindo mão da busca de uma verdade absoluta, assume a tarefa de construir discursivamente uma outra verdade, mais humilde e modesta, uma "verdade local e efêmera que é, no entanto, a única com a qual a decisão prática pode contar, e só ela pode responder à urgência da vida moral e política". ADVERSE, Helton. Retórica, Educação e Política no Renascimento italiano. Sapere Aude, v. 2, n. 4, 2011, p. 8-19.

13 SEIGEL, Jerrold E. "Civic humanism" or Ciceronian rhetoric? The culture of Petrarch and Bruni. Past \& Present, v. 34. n. 1, p. 3-48, 1966, p. 27; HANKINS, James. The "Baron Thesis"... Op. cit., 1995.

${ }^{14}$ RUBINSTEIN, N. Il Bruni a Firenze: retorica e politica. In: Leonardo Bruni cancelliere della repubblica di Firenze. Convegno di studi a cura di P. Viti. Firenze: [s.n.], 1990. Sobre salubridade, Bruni assevera que: "Não são poucas as cidades imundas que durante a noite produzem toda sorte de dejeto que de manhã se expõe aos olhos e pés de todos pelas ruas, coisa a mais fétida que se possa imaginar. [...] Do mesmo modo que um corpo disforme, ainda que tenha muitas partes perfeitas, não pode haver felicidade, também nas cidades, se forem imundas, ainda que lhes esteja presente todo o resto, não pode haver de modo nenhum, beleza". (Bruni, Laudatio, § 7). "Florença, de fato, até onde podemos discernir é a tal ponto salubre e limpa que não se pode encontrar nenhuma outra mais brilhante. Esta cidade é única e, em todo o orbe terrestre, só nela nada ofende aos olhos, nada é desagradável ao nariz, nem nada é imundo aos pés. Dada toda a diligência suprema dos habitantes, assim como suas precauções e cuidados, todas as imundícies são afastadas para longe, de modo que apenas se encontre pelo caminho alegria e gozo dos sentidos". (Ibidem, § 8).
} 
a defesa da cidade contra as acusações de Gian Galeazzo Visconti, duque de Milão, e sua tradicional legitimidade. ${ }^{15}$ Não podemos esquecer a tese de Hans Baron, cujo motivo fundamental do conflito estava não apenas no expansionismo unilateral dos Visconti, mas no embate entre dois expansionismos: o milanês e o florentino (podemos lembrar, por exemplo, da aquisição de Arezzo, em 1384, e a rápida evolução e radicalidade do projeto). Para desenvolver este ponto Salutati avança e equipara o cidadão de Florença àquele de Roma.

$\mathrm{Na}$ Laudatio este argumento se radicaliza, tendo como base o Panatenaico, de Elio Aristides. ${ }^{16}$

\begin{abstract}
Como diz Cícero, "sou da opinião de que devemos começar do princípio". De onde, portanto, se origina este povo? Quais foram seus ancestrais? Por quais mortais esta ilustre cidade foi fundada? Reconhecei, florentinos, reconhecei vossa estirpe e vossa linhagem! Considerai que de todas as gentes sois os mais ilustres! Os outros povos têm como ancestrais refugiados ou banidos de suas pátrias, camponeses, imigrantes obscuros ou fundadores desconhecidos. Os vossos fundadores, entretanto, foram os romanos, conquistadores e senhores de todo o orbe terrestre. Ó Deus imortal, foram conferidas tantas coisas boas a esta única cidade de tal modo que tudo parece ter contribuído para sua beleza. De primeira importância é: os florentinos têm sua origem no povo romano! Que outra nação no mundo inteiro foi mais ilustre, mais poderosa, que mais se destacou em todas as virtudes que a romana? [...] De fato, se buscas nobreza entre os fundadores, não encontrarás ninguém mais nobre no mundo inteiro que o povo Romano. Se procuras riqueza, ninguém mais rico; se procuras grandeza e magnificência, ninguém mais excelente nem mais glorioso; se procuras extensão de domínio, nada do lado de cá do oceano deixou de se curvar às armas e ao poder de Roma. Desse modo, Florentinos, a vós pertence por hereditariedade o direito de domínio sobre todo o orbe terrestre e a posse de tudo que outrora fora de vossos pais. (Bruni, Laudatio, § 30-31). ${ }^{17}$
\end{abstract}

15 O humanista e chanceler florentino Coluccio Salutati escreveu, entre outros trabalhos, a Invectiva contra Antonio Loschi de Vicenza, em resposta às críticas dirigidas à Florença por Antonio Loschi, representante de Milão, que a acusava de tirania. Um dos tantos pontos altos deste panegírico é a aflorada defesa da cidade e de sua liberdade, associada, nesse contexto, à vida cívica e à forma de governo republicana. Salutati responde a Loschi e acusa o governo de Milão de tirania pois, Florença, que cultiva tão fervorosamente a liberdade não poderia tolerar tal injúria. Para a leitura completa deste texto, ver: SALUTATI, Coluccio. Invective Against A. Loschi. In: BALDASSARI, S. Coluccio Salutati Political Writings. London: The I Tatti RenaissanceHarvard University Press, 2014.

${ }_{16}$ ARISTIDES, Elio. Panatenaico. In: Discursos I. Introducción, traducción y notas de Fernando Gascó y Antonio Ramirez de Verger. Madrid: Credos, 1987, p. 113-254. Já tratamos destas aproximações entre o Panatenaico e o Elogio em outros artigos. Para não nos alongarmos nesta digressão, cito aqui mais uma vez a referência do estudo realizado e publicado pela revista Morus. PINTO, Fabrina M. O Elogio da cidade... Op. cit., p. 243-335. Não há um critério unânime sobre quando foi pronunciado o Panatenaico. Alguns autores acreditam ter sido em 155, e outros em 167. No que tange à forma, se trata de um panegírico de uma cidade semelhante a outros que Aristides escreveu. Com este discurso o sofista se somava a uma larga tradição de elogios de Atenas; em especial àquela dos elogios fúnebres. Contudo, ainda que não trate de uma temática nova, temos notícias sobre o atrativo destes elogios entre diversos autores da época. Cf.: LORAUX, N. L'Invention d'Athènes. Histoire de I'oraison funèbres dans la cité classique. Paris: Mouton; Éd. I'EHESS, 1981.

17 Associado ao tom político e propagandístico da Laudatio, está o fato de que, se Florença tem pleno direito à hereditariedade romana, ela também teria o mesmo direito à expansão e conquista de outras cidades; sendo assim, todas as guerras seriam justas porque defenderiam a causa republicana e a reconquista dos territórios perdidos no passado medieval. A escolha de Bruni em alterar o argumento da fundação da cidade o permite justificar, ao mesmo tempo, a guerra contra o papa e contra Giangaleazzo Visconti. VASOLI. Considerazioni sulla Laudatio Urbis Florentinae di Leonardo Bruni. In: Estrato dall'Annuario 1961-1962 del Liceo Ginnasio Statale F. Petrarca di Arezzo. Vol. XXXV I. Firenze: Istituto Nazionale di Studi sul Rinascimento, 1961-1962, p. 11. 
Florença foi fundada, portanto, antes que César ou Antônio viessem a acabar com a liberdade; passando a relatar na sequência todos os males que os tiranos fizeram à república (Bruni, Laudatio, § 33-35; 44).

Não se pode deixar de ressaltar que esta questão sobre a origem romana do povo florentino é, diga-se de passagem, bastante original tanto em relação ao modelo de Aristides quanto em relação aos elogios medievais. Esta temática passa a ser um objeto constante do republicanismo florentino - sendo visível no Diálogo a Pier Paulo Vergerio e na História do Povo Florentino de Bruni, e que retorna, pouco depois, em autores como Maquiavel, Guicciardini e Giannotti. ${ }^{18}$ Não é demais sublinhar que este tema histórico-arqueológico apresenta uma forte conotação política e ideológica, não sendo por acaso que Bruni afirma, contra todas as outras teses e tradições, a ideia de que Florença tenha sido fundada como colônia romana ainda no tempo em que vigorava a liberdade republicana, e que, portanto, apenas esta cidade toscana poderia proclamar-se possuir a legítima tradição romana; e, além disso, manter o mesmo status político de cidadania desfrutada pelos habitantes de Roma. Uma evidência importante que diferencia uma colônia republicana de uma submissa ao império é que, segundo Bruni, os imperadores repudiavam os valores caudatários da república. Assim, segundo Vasoli, o aspecto histórico mais interessante da afirmação dessa tese contraposta à historiografia medieval, "consiste no espírito anti-imperial que a inspira; no modo pelo qual Bruni abandona decisivamente o mito medieval da romanidade imperial para dedicar-se a uma visão da história de Roma estritamente 'cívica' e 'republicana' [...]. Na Laudatio, a polêmica antiimperial é agora estritamente ligada à defesa da particular função histórica de Florença, e há um precioso intento propagandístico". ${ }^{19}$

Ao final desta segunda parte, Bruni introduz, assim como Elio Aristides, as ações pacíficas e virtuosas que ressaltam a beneficentia de Florença (Bruni, Laudatio, § 49-74); ${ }^{20}$ exata transposição da philantropia ateniense. Essa benevolência, passada e atual, é ilustrada por atos particulares dos cidadãos, sendo clara a alusão ao sofista grego que trata deste ponto em quase um terço do Panatenaico (louvando a grandeza dos atenienses na Guerra do Peloponeso e nas guerras persas). ${ }^{21}$ Para Aristides, Atenas é a cidade ideal para acolher os refugiados e exilados; "pois esta cidade, desde o princípio, se ofereceu ela mesma como patrimônio para os que estavam em necessidade" (Aristides, Panatenaico, cap. 54). Essa discussão se estende ainda pelos parágrafos 55 a 74, onde o autor explora o tema da

\footnotetext{
${ }_{18}$ Para a tradução do Diálogo a Pier Paulo Vergerio, ver: BIGNOTTO, N. Origens do Republicanismo... Op. cit., p. 257-282.

19 VASOLI. Considerazioni sulla Laudatio... Op. cit., p. 10-11.

${ }^{20}$ Utilizaremos aqui a tradução: ARISTIDES, Elio. Panatenaico. Op. cit., p. 113-254. Não há um critério unânime sobre quando foi pronunciado o Panatenaico. Alguns autores acreditam ter sido em 155, e outros em 167. No que tange à forma, se trata de um panegírico de uma cidade semelhante a outros que Aristides escreveu. Com este discurso o sofista se somava a uma larga tradição de elogios de Atenas; em especial àquela dos elogios fúnebres. Contudo, ainda que não trate de uma temática nova, temos notícias sobre o atrativo destes elogios entre diversos autores da época. Cf.: LORAUX, N. L'Invention d'Athènes. Op. cit.

${ }^{21}$ Este argumento da beneficência dos cidadãos é um dos pontos centrais para que o humanista desenvolvesse a associação entre a beneficentia florentina e a necessidade de expansão das suas instituições para as outras repúblicas da península itálica.
} 
benevolência ateniense em acolher e admitir os necessitados, bem como torná-los partícipes de seu território, leis e constituição. Contudo, após aceitar todos os homens, Atenas poderia utilizar este excedente populacional a favor da Hélade, enviando expedições colonizadoras, colocando chefes à frente de cada uma, e transformando antigos postos refugiados em grandes cidades. É deste modo que o autor justifica a expansão política e territorial grega, tendo em vista que: "como poderia haver algo mais benévolo para os que nela confiavam?" (Aristides, Panatenaico, cap. 70). Da benevolência de seus cidadãos e da sua linhagem divina desenvolve-se todo o argumento. "Como não será consistente enviar enxames de colônias e povoar a terra?" (Aristides, Panatenaico, cap. 74).

Para Bruni, o ápice da grandeza consumada pelos atenienses corresponderia à suprema grandeza alcançada pelos florentinos em suas guerras contra o "todo poderoso duque de Milão", tanto que, se aquela guerra antiga superava todas aquelas que a antecederam (Tróia), agora "as conquistas de Florença eram tão memoráveis quanto aqueles grandiosos acontecimentos da Antiguidade". Um dos pontos que sustenta a sua tese é a questão da beneficência; posto que a cidade que age bem deve levar seus costumes a outros lugares. Diz Bruni:

Por causa disso, todos aqueles que se viram expulsos de sua terra natal por sedições ou exilados por inveja se voltam para Florença como único refúgio e proteção de tudo. Assim, não há ninguém em toda Itália que não se considere possuindo dupla nacionalidade: privadamente a da cidade à qual pertence, publicamente a de Florença. (Bruni, Laudatio, § 54). ${ }^{22}$

Disso resulta que ela seja a pátria comum e o asilo seguro para toda a Itália. Aqui todos, quando precisam, são recebidos pelos habitantes com graça e grande boa vontade. De fato, o zelo pela beneficência e cortesia nesta República é tão grande que parece clamar em alta voz de tal modo que todos o podem ouvir, não podendo ninguém se considerar apátrida enquanto existir a cidade dos florentinos. (Bruni, Laudatio, § 55).

Segundo o chanceler, uma série de cidades, quando oprimidas por conspirações de vizinhos ou por violência de tiranos, foram socorridas pela ajuda e pelo dinheiro de Florença, de modo a atravessarem os tempos difíceis.

Que cidade gastou tanto dinheiro, suportou tantos encargos e empreendeu tão incríveis riscos em prol da defesa de outras cidades? Dado que Florença tenha defendido em momentos de perigo outras cidades, torna-se praticamente necessário que elas a considerem sua patrona. Quem negará, sendo ela patrona, sua excelência em dignidade, em poder, em produção econômica e em autoridade? (Bruni, Laudatio, § 58).

\footnotetext{
22 Também no texto de Aristides (Panatenaico, cap. 54), Atenas é a cidade ideal para acolher os refugiados e exilados; "pois esta cidade, desde o princípio, se ofereceu ela mesma como patrimônio para os que estavam em necessidade". Essa discussão se estende ainda pelos capítulos 55 a 74 , onde o autor explora o tema da benevolência ateniense em acolher e admitir os necessitados, bem como torná-los partícipes de seu território, leis e constituição. Contudo, após aceitar todos os homens, Atenas poderia utilizar este excedente populacional a favor da Hélade, enviando expedições colonizadoras, colocando chefes à frente de cada uma, e transformando antigos postos refugiados em grandes cidades. É deste modo que o autor justifica a expansão política e territorial grega, tendo em vista que: "como poderia haver algo mais benévolo para os que nela confiavam?" (Ibidem, cap. 70). Da benevolência de seus cidadãos e da sua linhagem divina desenvolve-se todo o argumento. "Como não será consistente enviar enxames de colônias e povoar a terra?" (Ibidem, cap. 74).
} 
Destaca-se, portanto, na Laudatio a associação entre o argumento da herança romana de Florença e o seu direito de conquista. Se todas as suas guerras foram justíssimas e voltadas para o domínio universal, as mesmas ações poderiam ser realizadas pelos florentinos. Florença se torna a patrona da liberdade republicana, opondo-se à força dos opressores, seja na luta contra o imperador Henrique VII e na defesa da cidade contra o seu assédio, seja nos recentes conflitos iniciados com Milão. ${ }^{23}$ Segue-se disso que todas as guerras feitas pelo povo de Florença são justas, e nunca faltará justiça às guerras feitas por esse povo, pois elas são pela defesa ou reconquista de seu próprio território.

Bruni escolhe então três eventos históricos para analisar o comportamento florentino: o primeiro é o episódio de Volterra, o segundo a guerra entre Lucca e Pisa e o terceiro trata do conflito entre Florença e Milão, em $1402 .{ }^{24}$ Diferentemente dos dois primeiros eventos, que já faziam parte do passado florentino, este último trata de um problema que envolvia toda a Itália (tendo em vista a expansão das conquistas do duque de Milão). Florença teria que enfrentar, para assegurar os interesses republicanos, o inimigo mais rico, mais forte e mais temido da península. A ameaça de Giangaleazzo Visconti, que "causa o terror dos povos transalpinos assim como de todo o resto da Itália" (Bruni, Laudatio, § 17), só poderia ser contida pela bravura dos florentinos, bem como pelo desejo destes cidadãos em cuidar dos outros povos italianos e Ihes assegurar uma vida segura e livre.

A liberdade só é possível com a salvaguarda da liberdade cívica, proporcionada pelo sistema republicano, ressaltando em vários momentos a importância da resistência contra seus inimigos e, sobretudo, contra a expansão milanesa.

Quem em toda a Itália poderia ser comparado àquele inimigo em poder e diligência? Ou quem resistiria aos esforços daquele cujo mero nome era motivo de terror para todos os mortais? Realmente não apenas a Itália, mas os povos transalpinos também temiam sua fama. Ele estava, sim, muito bem guarnecido de recursos, dinheiro e homens, mas bem mais de estratagemas e astúcia. E ele tinha grande e formidável poder: toda a Gália cisalpina e quase todas as cidades que, desde os Alpes até a Etrúria e a via Flamínia se encontram entre dois mares, estavam sob seu poder e obedeciam a suas ordens. Na Etrúria ele tomou Pisa, Siena, Perúgia e Assis, por último ocupou também Bolonha. Muitas fortalezas, muitos poderosos e nobres - seja por temor, seja por esperança de rapinagem, seja por terem sido enganados - seguiram seu nome e fortuna. (Bruni, Laudatio, § 70).

${ }^{23}$ Sobre os primeiros conflitos com os milaneses, ver: NAJEMAY, John. Storia di Firenze... Op. cit., p. 238-251.

${ }^{24}$ O episódio de Volterra ocorreu em 1254, e foi descrito com mais detalhes na História, de Bruni. BRUNI, Leonardo. History of the Florentine people. Harvard University Press, 2001-2007. 3 vols.

Hans Baron acredita que, nos anos subsequentes à morte do duque de Milão, foram escritos inúmeros textos valorizando a participação pública e a organização política florentina, gerando uma ruptura decisiva com o passado anterior à guerra. E, dentre os autores elencados, Baron dedica uma especial atenção a Bruni, sobretudo ao Diálogo a Pier Paulo Vergerio, que deve ser entendido como o texto fundador do humanismo cívico por tratar de uma nova maneira o passado romano, conectado a Florença pela fundação desta cidade por repúblicas etruscas, e não, como se acreditava nos séculos XIII e XIV, por forças romanas do período imperial. BARON, $\mathrm{H}$. The crisis of the early Italian renaissance: Civic Humanism and republican liberty in an age of classicism and tyranny. New Jersey: Princeton, 1966 [1955], p. 47-78. Foram muitas as críticas a esta interpretação de Baron. Apenas para citar alguns exemplos, podemos vê-las claramente expostas nos trabalhos de Hankins, Gene Brucker, e John Najemy. Cf.: HANKINS, James. The "Baron Thesis"... Op. cit.; BRUCKER, Gene. Dal Comune alla Signoria. La vita publica a Firenze nel primo Rinascimento. Bologna: [s.n.], 1981; NAJEMAY, John. Storia di Firenze... Op. cit. 
Assim é forjada, nesta primeira parte dedicada às ações exteriores, uma ideia que passa a ganhar cada vez mais amplitude: a hegemonia justa e quase natural de Florença sobre o resto da Itália. ${ }^{25}$

\section{As instituições da cidade ideal}

Não obstante a enorme bibliografia sobre o humanismo e Bruni em particular, algumas destacando o papel da história e do discurso retórico, estando ou não em contradição mútua, chama à atenção o fato de que quase nada tem sido relevado a respeito do papel desempenhado pelas instituições políticas no pensamento de Bruni. ${ }^{26}$ É como se essa dimensão da reflexão fosse de tal maneira moderna que deveria esperar ao menos um século para que pudesse ser levada a sério. De fato, não encontramos em Bruni um tratamento sistemático do funcionamento institucional da cidade ideal e, mesmo em sua análise histórica sobre Florença, esse não é um tema de destaque. Todavia, a marcante presença de Aristóteles, Políbio e Cícero em suas obras levanta a questão a respeito das formas de governo e, em conjunção com seu projeto, do governo ideal. Ainda que não se possa afirmar a presença de uma teoria robusta e autônoma das formas de governo e sua idealização, há importantes passagens em sua obra que anunciam os termos centrais do regime republicano renascentista, isto é, a seguridade entre as relações internas e externas da cidade, um sistema de direito criminal equitativo, a liberdade da cidade e do cidadão e, por fim, o governo misto.

Sobre o primeiro ponto, pode-se dizer, todo seu esforço argumentativo no Elogio gira em torno do convencimento daquele que o lê sobre a importância da participação e na defesa da cidade. Trata-se, afinal, de um evidente pressuposto de suas colocações, qual seja, a liberdade da cidade e do cidadão estão intimamente conectadas e interdependentes. Isso significa que, antes de uma embocadura somente conceitual a respeito do que seja a liberdade, as instituições da cidade de Florença estão preparadas para assumir as responsabilidades dos assuntos tanto "de dentro" quanto "de fora". "Esta cidade é, de fato, admirável por suas relações externas, mas não é menos pela sua disciplina nas instituições

\footnotetext{
25 Já vimos este mesmo argumento em partes iniciais da Laudatio. Na primeira parte a hegemonia florentina é assegurada pela riqueza e esplendor da cidade (Bruni, Laudatio, § 25). E na segunda, Bruni afirma que os florentinos são os dignos descendentes do povo que dominou a terra inteira (Ibidem, cap. 34). E o encontramos novamente na terceira parte, quando Florença é chamada pelos italianos para lutar contra o inimigo milanês e recuperar a sua superioridade de chefe da Itália: "é por eles que essa cidade luta, é por eles que ela obtém preponderância e glória" (Ibidem, § 72-74).

${ }^{26}$ Diante da vastidão de textos sobre o Humanismo e da impossibilidade de citar todas as grandes obras de referência, optamos por indicar apenas o volume a seguir, onde se pode encontrar um excelente balanço sobre o conceito e sobre os muitos debates em torno do tema: The Cambridge Companion to Renaissance Humanism (Cambridge Companions to Literature). Cambridge, UK: Cambridge University Press, 1996. Em relação à discussão em torno do conceito de "humanismo cívico", cf.: HANKINS, James (org.). Renaissance Civic Humanism: reappraisals and reflections. Cambridge: Cambridge University Press, 2000. Incluindo sua bibliografia.

Sobre Bruni, podemos citar alguns trabalhos que nos ajudam a compreender o autor e a sua vasta obra. Conferir, na bibliografia deste artigo, os textos de Baron (1955; 1968; 1993), Garin (1963; 1965; 1976; 1996); Viti (1992; 1996); Vasoli (1961-1962; 1972); Pradelle (2008; 2014); Hankins (1995; 2000); Rubinstein (1986); Fubini (2003); entre tantos outros.
} 
domésticas. Em nenhum outro lugar há tanta ordem nas coisas; em nenhum outro lugar, tanta elegância; em nenhum outro lugar, tanta unidade" (Bruni, Laudatio, § 76).

Bruni passa ao seu último capítulo, sobre as Ações e virtudes interiores de Florença, ressaltando, sobretudo, as suas instituições republicanas. Assim como em Satutati, tem-se um jogo de oposições entre o modelo republicano e o modelo tirânico, representado por Milão entre o governo de muitos e o governo de um só homem. Segundo Vasoli: "a Florença vencedora deste conflito contra Milão, que há superado a mais grave prova da sua história enquanto cidade-estado, deve, contudo, a sua força política e a sua resistência militar ao sistema constitucional que soubera criar, à ordem de seus magistrados e a seus conselhos". ${ }^{27}$ De acordo com o autor, é com esta ideia, provavelmente difusa ainda entre os intelectuais e dirigentes da sociedade florentina, que Bruni conclui a Laudatio com uma análise da constituição florentina, sendo este ponto de extremo interesse para a construção do ideário do humanismo cívico; conforme analisado por Hans Baron, em The Crisis of the Early Italian Renaissance. $^{28}$

A elegância e a ordem são elogios complementares à característica que verdadeiramente importa, a de que Florença possui perfeição na unidade entre os tratamentos de temas internos e externos, pois, supõe-se pelo menos desde Salutati, que uma arregimentação malfeita resultaria em alguma forma de desequilíbrio e, portanto, comprometeria a outra parte. O papel do cidadão está para o do soldado assim como suas instituições que tratam de temas internos estão para as representações diplomáticas e, sobretudo, as artes da defesa militar. Um dos pontos que pode ser lido em Políbio (História, livro VI ${ }^{29}$ diz respeito exatamente à interdependência entre a ordenação para a defesa e/ou expansão e o tratamento adequado de seus cidadãos. Nenhuma cidade seria capaz de convencer seus cidadãos a defendê-la se não tiverem apreço por ela, ao mesmo tempo, ninguém defenderia uma cidade cujo governo não seja considerado legítimo. Entende-se, assim, porque já se anuncia em Bruni temas militares que entrariam em voga no século seguinte, tais como: a disciplina do cidadão-soldado e o papel da artilharia de sua cidade. Quando um regime ilegítimo visa arrebanhar soldados tende, sempre, a encontrar resistência. Por isso, a sequência do último passo diz respeito ao tratamento despendido aos cidadãos e a condição livre deles e da cidade:

\begin{abstract}
Antes de tudo, portanto, há de se cuidar para que a justiça seja sagrada nesta cidade, pois sem justiça não pode haver cidade, nem Florença poderia ser chamada de cidade. Em seguida, que haja liberdade, pois sem liberdade este povo nunca consideraria valer a pena viver. A estes dois pontos interligados, como a um estandarte ou a um porto, se direcionam todas as instituições e decisões da República. Para o favor da justiça instituíram-se os magistrados, aos quais foi dada a autoridade de punir os criminosos, mas principalmente de providenciar para que nenhum poder valha nesta cidade mais que as leis. (Bruni, Laudatio, § 77).
\end{abstract}

\footnotetext{
27 VASOLI. Considerazione sulla Laudatio... Op. cit., p. 17.

${ }^{28}$ Cf.: BARON, $\mathrm{H}$. The crisis of the... Op. cit.

29 POLÍBIO. História. Brasília: Ed. UnB, 1985, livro VI.
} 
R. Fubini, em La rivendicazione di Firenze dela sovranità statale e il contributo dele Historiae di Leonardo Bruni, mostra como para o humanista a justiça não pode ser confiada ao exercício imparcial dos Rettore, mas sim no poder atribuído aos magistrados. Segundo o autor, Bruni se referiria nesta passagem às instituições medievais e a figura dos rettori forasteiros; como o podestá, a quem era atribuído o exercício da justiça e o primeiro posto na hierarquia dos poderes citadinos. ${ }^{30}$ De acordo com Baron, foi Florença a cidade que mais se empenhou em deter o avanço dos déspotas nessa época, conseguindo fazer frente, durante todo o século XIII, a cada um dos desafios externos que puseram em xeque a sua independência, sendo esses esforços para resistir ao triunfo dos signori acompanhados pelo desenvolvimento de um ideário político que tinha em mira defender e realçar as virtudes distintivas da vida cívica republicana. Assim, argumenta que jamais houve uma defesa da liberdade republicana até os humanistas cívicos florentinos do início do Quattrocento. ${ }^{31}$ A mesma tese foi reiterada por vários outros historiadores de inícios da Renascença, tais como Hyde e Holmes. Desta interpretação se distancia Skinner, entre outros. ${ }^{32}$

Apesar da reminiscência tradicionalmente medieval do tema da justiça, pouco afeito à tradição republicana, o trecho expressa bem as características centrais do republicanismo do renascimento italiano. A liberdade coaduna as vontades e os anseios dos cidadãos com os da cidade, formando um bloco unitário e inquebrável, tipicamente ciceroniano, entre benefícios públicos e privados. Sabe, cada citadino, que não pode viver bem, aristotelicamente, sem que a cidade seja bem constituída e sua constituição depende da ação dos cidadãos.

O que Bruni aqui nomeia de justiça não é propriamente um conceito ou uma versão atualizada de uma filosofia antiga, mas o cumprimento exíguo dos critérios de equidade na aplicação da distribuição de censuras, penas e honras por parte de magistrados legitimados pelo corpo de cidadãos. Todas as instituições da república dependem dessa interligação justamente pelo fato de que uma e outra dependem mutuamente, sem justiça não há liberdade e vice-versa. É preciso destacar ainda que todos, principalmente os governantes, estão submetidos a um regime legalista. O império das leis não apenas torna a justiça efetiva e garante a liberdade, mas sobretudo limita o acúmulo de poder privado. Fica evidente aqui que Bruni projeta nas instituições florentinas um antimonarquismo radical, que se tornará uma pedra de toque de todo o republicanismo moderno. Não se pode confundir poder público com privado e menos ainda o poder de um homem sobre o agregado da cidade, este sim se faz através das leis, às quais todos se submetem.

Até esse ponto, têm-se alguns paradigmas institucionais bem claros: a necessária conexão entre instituições e as ações externas e internas, as garantias de tratamento equânime diante de regras generalistas, liberdade da cidade e do cidadão em conformidade mútua, antimonarquismo e império da lei. Todas essas características são expressões

\footnotetext{
30 FUBINI. La rivendicazione di Firenze dela sovranatà statale e il contributo dele Historiae di Leonardo Bruni. In: Leonardo Bruni cancelliere dela Repubblica di Firenza. Firenza: Leo Olshki, 1990, p. 37-38.

${ }^{31}$ BARON, $\mathrm{H}$. The crisis of the... Op. cit., p. 49; 58.

32 SKINNER, Quentin. Fundações do Pensamento... Op. cit., p. 49.
} 
fundantes do republicanismo moderno e não, como às vezes se aponta, de uma forma utópica de conceber as cidades.

Bruni não cai na armadilha, comumente atribuída à tradição estoica, de supor um funcionamento perfeito desses ideais em formas institucionais, pois são também necessárias outras garantias que não apenas a devida compreensão de todos sobre o papel das leis e do povo e a correta aplicação das leis. Afinal, regimes tirânicos emergem mesmo em cidades cujas leis são precisas. Não basta, portanto, para Bruni uma solução à moda dos antigos, como o império da lei e o dever cívico abnegado, é preciso também que o poder esteja disperso o suficiente para que um magistrado eleito não fique tempo suficiente para se tornar tirano, como bem ensinou Políbio (História, livro VI), nem acumule poder demasiado para que a autoridade se confunda com a arbitrariedade, como prediz Cícero, (Dos deveres, livro III). ${ }^{33}$

Aos magistrados, então, tanto indivíduos particulares quanto homens de um grupo social inferior são compelidos a obedecer e a respeitar. Mas para que eles não possam, como vindica a lei, considerar-se dotados de todo o poder, sendo levados assim não à proteção dos cidadãos, mas à tirania, e para evitar que pudessem coagir quem quer que fosse, enfraquecendo a suma liberdade, muitas precauções foram tomadas. Primeiramente, o posto de magistrado supremo, que é visto como possuindo quase o poder de um soberano, é moderado por certas medidas, como para ele ser nomeado não apenas um magistrado, mas nove, e cada um exercer o cargo não por um ano, mas por dois meses. Considerou-se, desse modo, administrar-se a República esplendidamente, pois com numerosas sentenças se evitavam os erros de julgamento e com a brevidade do mandato, a insolência. (Bruni, Laudatio, § 78).

Nas comunas medievais o podestà detinha largo poder, já que the cabia o papel de principal funcionário da cidade tanto no plano judicante quanto no administrativo. Mas, entre as suas principais características Skinner. ${ }^{34}$ ressalta: era um funcionário assalariado e nunca um governante independente, eleito pelo voto popular e seu tempo de governo costumava limitar-se a 6 meses. Deveria ainda ser cidadão de outra cidade, após o seu mandato era obrigado a um exame formal de suas contas, e geralmente governava consultando dois conselhos - o conselho maior poderia chegar até 600 membros, enquanto o conselho menor era limitado a uns 40 cidadãos de maior destaque. Bruni substitui este funcionário único pela figura de nove magistrados que exerceriam o poder por apenas dois meses. Em sua elaboração de uma cidade ideal, este aspecto traria mais igualdade nas decisões políticas; embora na Florença real o que acontecia era justamente o contrário, sobretudo após a revolta dos Ciompi, em 1378.

A dispersão do poder e a pequena duração do mandato são, na verdade, inovações brunianas, se lidas à luz de sua reflexão com os antigos. Uma consequência inadvertida de ambos os paradigmas, não anunciada pelo autor, mas inevitável diante de suas propostas, é uma participação efetiva de muitos cidadãos em cargos da magistratura. Ora, se o mandato é tão curto e se a instituição mais poderosa é ampliada de uma para nove vagas, não se pode concluir nada muito diferente do que uma radical abertura para a participação popular, tendo

\footnotetext{
${ }^{33}$ CÍCERO. Dos Deveres. São Paulo: Martins Fontes, livro III.

34 SKINNER, Quentin. Fundações do Pensamento... Op. cit., p. 25-27.
} 
em vista apenas que ele não é favorável a qualquer sistema oligárquico de governo. Todavia, o ponto alto de sua proposta institucional ainda está por vir:

Além disso, a cidade foi divida em quatro, de tal modo que nenhuma secção ficasse privada de representação. De cada uma elegem-se dois representantes oficiais, os quais não são escolhas fortuitas, mas homens conhecidos e considerados apropriados para tão digno cargo. Para governar a República, unese a esses oito cidadãos um homem ainda, superior em virtude e autoridade, vindo a cada vez de uma dessas mesmas secções, que é o príncipe do colégio a empunhar a bandeira da justiça contra os arruaceiros. Não se quer que esses nove homens, encarregados de governar a República, habitem outro lugar que a cidadela pública nem que andem a sua frente os lictores, ornando-lhes assim toda uma pompa e Ihes atribuindo uma majestade ainda maior. (Bruni, Laudatio, § 79).

Repare-se que todas as comunas são representadas, e por alguém legitimado localmente. Isso, em si mesmo, é razão suficiente, observado diante do sistema de rotação da magistratura superior, para que haja não apenas um rodízio entre um punhado de cidadãos, mas entre membros das diferentes regiões da cidade. Não vai aqui nenhum lance teórico antecipador do federalismo, mas, antes disso, uma corroboração do cidadão-soldado, visto que os alistamentos militares eram realizados de acordo com a distribuição dos habitantes pelos bairros, o que exigia de cada localidade uma tarefa própria, pois, em eventual situação de guerra ou invasão, cada lugar deveria estar preparado para defender o seu vizinho, contraatacar ou se reagrupar em torno da sede do governo.

A eleição de um representante conforma a acima citada unidade da cidade, dado que a respeitabilidade local é transmitida para toda a Florença. O príncipe do colégio, instituição caracteristicamente assemelhada ao senado, é explicitamente rotativo entre as regiões, de tal maneira que todas se sentem parte e responsável pelo todo da cidade. Por fim, está embutida na forma eleitoral de controle interno dos poderes: dos nove magistrados, oito são eleitos igualmente nos bairros e um, superior aos demais, por um bairro por vez.

\begin{abstract}
Sendo verdade, no entanto, que algumas vezes surgem situações que parecem precisar de maior capacidade de julgamento, somam-se ainda doze homens bons, que com os outros nove decidem as questões da República. Somam-se ainda os representantes da juventude, aos quais, quando Ihes couber proteger a liberdade, concorrem todos e todos os seguem. Eles têm assento no conselho e (assim como os magistrados) se elegem nas quatro seç̧ões e têm, por sua vez, mandato de quatro meses. (Bruni, Laudatio, § 80). ${ }^{35}$
\end{abstract}

Estamos aqui diante do ápice da institucionalidade bruniana. O poder da república se divide em três organismos distintos, separados desde suas respectivas origens, mas suficientemente relacionados mutuamente, de tal maneira que um seja capaz de controlar o outro. A referida capacidade de julgamento diz respeito a toda e qualquer deliberação e ação da cidade. Os doze cidadãos bons servem simultaneamente de contrapeso e auxílio à magistratura dos nove antes comentada. Observem-se ainda os representantes da juventude

35 De acordo com Bernard-Pradelle, o conselho dos Doze é um remanescente do Colégio dos Doze cônsules que, no século XII, já se revezavam a cada dois meses para exercer o poder executivo. BERNARD-PRADELLE, Laurent. Leonardo Bruni Aretino. Histoire, éloquence et poésie à Florence au début du Quattrocento. Textes choisis, édités et traduits par Laurence Bernard-Pradelle. Paris: Honoré Champion, 2008, p. 289. 
que, ao contrário dos magistrados, têm o dobro de tempo de mandato. Duas singularidades aqui podem causar estranheza ao leitor contemporâneo: o critério da idade e a maior duração do mandato em uma casa baixa. Trata-se, inusitadamente, de uma completa inversão dos ditames do governo misto dos antigos.

A separação dos poderes de inspiração aristotélica e a divisão de funções de base polibiana supõem, ambas, prerrogativas específicas de determinados órgãos governamentais a fim de cumprir com a coesão da cidade, a sua autonomia frente às demais e, sobretudo, o império das leis. Para isso, a dimensão aristocrática ou oligarca do governo misto requer, sobretudo a partir do alardeado exemplo histórico da república romana, o acúmulo de poder levemente superior à dimensão democrática, ou aos tribunos da plebe, se seguirmos Roma. Os senadores (do latim, senex, velho), correlato romano do que a tradição medieval florentina corroborada aqui por Bruni chama de magistrados, possuem, como afirmado categoricamente no parágrafo 79, a superioridade das decisões na república florentina, por isso a necessidade de mais idade, e com ela mais experiência e moderação, e mandato mais longo, garantindo decisões bem refletidas e prudentes já que não é nada da ordem do dia que se está em jogo quando de qualquer decisão. Isso não significa que estejam sós no controle da cidade. Pelo contrário, é justamente porque há uma instância superior de comando que se necessita de instrumentos consultivos e limitadores. O lance teórico que nos interessa aqui é que Bruni atribui as duas características distintivas do senado, ou do magistrado, à instituição representante da democracia, forma mais dinâmica e potente, por isso, mais compelida às transformações rotineiras. Encaixa-se, assim, com perfeição que sejam os jovens - tema que perdurará no republicanismo florentino até meados do século XVI - aqueles responsáveis pela representação democrática. Aliás, sua função primordial, a de defender a liberdade, está em estreito compasso com a ideia, contida já em Platão, Aristóteles e Cícero, de que a democracia pura é o regime mais afeito às formas livres. Na mistura constitucional, seguida de perto por Bruni, a parte que cabe à democracia mantém a primazia da defesa da liberdade.

O que parece, a princípio, uma incoerência é que a essa instância democrática é atribuída uma característica fundamentalmente senatorial, o tempo de mandato. Não há elementos textuais suficientes que permitam identificar as justificativas para isso, muito provavelmente Bruni está aqui seguindo a tradição comunal florentina e não o governo misto dos antigos gregos e romanos, mas isso é matéria de mera especulação. Do ponto de vista teórico, ainda que não se identifique sua origem, Bruni acaba por sobrepor características democráticas às aristocráticas e não parece nada improvável que seja mais um modo de controle interno do poder, como o nono magistrado eleito em rotação geográfica.

Por fim, repare-se ainda que das três instâncias do governo republicano, a representação da juventude é a única com mandato descontínuo, é eleita quando necessário, isto é, quando a liberdade da cidade e/ou do cidadão estiver ameaçada, por um agente interno ou externo. A princípio, a participação somente esporádica da casa democrática poderia parecer uma fraqueza, mas na verdade é uma força. Ela não surge sem motivos nem em situações de normalidade política e, por isso mesmo, quando surge sua autoridade é mais 
respeitada do que um poder cotidiano comum. Deve-se lembrar que parte dessa potência democrática é revestida pelo fato de que a ela "todos concorrem". Mais uma vez Bruni parece aqui unir uma teoria política clássica com os paradigmas históricos de sua cidade, pois de tempos em tempos, desde o regime comunal medieval, todos os cidadãos eram convocados a fim de legitimar ou reformar as instituições políticas fundamentais de Florença. Portanto, não há como negar que Leonardo Bruni esteja efetivamente tratando das instituições de sua cidade, de modo absolutamente elogioso, tendo em mente as teorias antigas do governo misto.

\begin{abstract}
Esses três colégios não tiveram poder para resolver todas as questões. Mas muitas, sendo aprovadas por eles, são encaminhadas para o conselho geral do povo. No que diz respeito às pessoas em geral, não se deve discernir sentenças senão por meio justamente da maioria, procedimento que se julga estar de acordo com a justiça e com a razão. Desse modo vige a liberdade e se salvaguarda em sua sacralidade a justiça na cidade: que a vontade de um ou de outro não possa antepor-se ao julgamento de tantos homens. $E$, de fato, esses homens decidem sobre as questões da República, sancionam as decisões da justiça, abolem leis, estabelecem a paridade. Apresentam-se aí também magistrados menores que pronunciam a justiça por meio das leis ou a executam por meio da espada. Estes, na verdade, não são cidadãos da cidade, mas estrangeiros convocados à cidade justamente para isso. Tal se dá não porque os cidadãos de Florença não sabem realizar essas atividades (pois cotidianamente as realizam em outras cidades), mas para que não nasçam ódios e inimizades entre os cidadãos por causa de poderes judiciais. Muitos há que, ludibriados por excessiva autoestima, outorgam-se mais direitos que as leis lhes permitem. Esses mesmos, ainda que sejam julgados com justiça, antepõem querelas contras os magistrados. (Bruni, Laudatio, § 81). ${ }^{36}$
\end{abstract}

\footnotetext{
${ }^{36} \mathrm{O}$ Consiglio del Popolo era popular apenas em seu nome, tendo em vista que vários grupos sociais ficavam de fora. Para ser eleitor, era necessário fazer parte de uma das suas vinte e uma corporações; enquanto os trabalhadores eram organizados em setenta e dois sindicatos. BERNARD-PRADELLE, Laurent. Leonardo Bruni Aretino... Op. cit., p. 289. Segundo Skinner, várias repúblicas italianas contratavam estrangeiros para o governo, para que permanecessem no poder por tempo não superior a seis meses e não desenvolvessem vínculos com as principais famílias das cidades. SKINNER, Quentin. Fundações do Pensamento... Op. cit., cap. 1.
} 


\section{Referências}

ADVERSE, Helton. A matriz italiana. In: BIGNOTTO, Newton. Matrizes do Republicanismo Moderno. Belo Horizonte: Ed. UFMG, 2013.

ADVERSE, Helton. Retórica, Educação e Política no Renascimento Italiano. Sapere Aude, v. 2, n. 4, p. 8-19, 2011.

ARISTIDES, Elio. Panatenaico. In: Discursos I. Introducción, traducción y notas de Fernando Gascó y Antonio Ramirez de Verger. Madrid: Credos, 1987.

BALDASSARI, S. U. [Introduzione]. In: BRUNI, Leonardo. Laudatio Florentinae Urbis. Edizione di Stefano U. Baldassari. Firenze: Sismel, 2000

BARON, H. En busca del Humanismo Cívico florentino: ensayos sobre el cambio del pensamento medieval ao moderno. México: Fondo de Cultura Econômica, 1993.

BARON, H. From Petrarch to Leonardo Bruni: Studies in Humanistic and Political Literature. Chicago: University of Chicago Press, 1968.

BARON, $\mathrm{H}$. The crisis of the early Italian renaissance: Civic Humanism and republican liberty in an age of classicism and tyranny. New Jersey: Princeton, 1966 [1955].

BERNARD-PRADELLE, Laurence. Leonardo Bruni Aretino. Histoire, éloquence et poésie à Florence au début du Quattrocento. Textes choisis, édités et traduits par Laurance BernardPradelle. Paris: Honoré Champion Éditeur, 2008.

BIGNOTTO, Newton. Origens do Republicanismo Moderno. Belo Horizonte: Ed. UFMG, 2001.

Boulanger, A. Aelius Aristides et la sofistique dans la Provincie d'Asie au II siècle de notre ère. Paris: De Boccard, 1923.

BOWIE, E. L. Los Griegos y su Pasado en la Segunda Sofística. In: FINLEY, M. I. (ed.). Estudios sobre Historia Antigua. Madrid: [s.n.], 1981.

BRUCKER, Gene. Dal Comune alla Signoria. La vita publica a Firenze nel primo Rinascimento. Bologna: [s.n.], 1981.

BRUNI, Leonardo. Elogio da cidade de Florença. Tradução, revisão e notas de Alexander de Carvalho e Fabrina M. Pinto. Morus - Utopia e Renascimento, v. 11, n. 2, 2016.

BRUNI, Leonardo. History of the Florentine People. Cambridge, MA: Harvard University Press, 2001-2007. 3 vols.

BRUNI, Leonardo. Laudatio Florentinae Urbis. Edizione di Stefano U. Baldassari. Firenze: Sismel, 2000.

BRUNI, Leonardo. Laudatio Florentinae Urbis. In: BARON, H. From Petrarch to Leonardo Bruni: Studies in Humanistic and Political Literature. Chicago: University of Chicago Press, 1968.

BRUNI, Leonardo. Laudatio Florentinae Urbis. In: Histoire, Éloquence et Poésie à Florence au début du Quattrocento. Textes choisis, édites et traduits par Laurence Bernard-Pradelle. Paris: Honoré Champion, 2008.

BRUNI, Leonardo. Laudatio Florentinae Urbis. In: VITI, P. Opere Letterarie e Politiche di Leonardo Bruni. Torino: Unione Tipografica-Editrice Torinese, 1996.

BRUNI, Leonardo. Panegirico della Città di Firenze. In: TOFFOL, G. de. Testo italiano a fronte di Frate Lazaro da Padova. Firenze: La Nuova Italia, 1974. 
CAMBIANO, Giuseppe. L'Atene nascosta di Leonardo Bruni. Rinascimento. Rivista dell'Istituto Nazionale di Studi sull Rinascimento, Firenze, v. XXXVIII, 1998.

CÍCERO. Dos Deveres. São Paulo: Martins Fontes, 1999.

FUBINI, Ricardo. La rivendicazione di Firenze dela sovranità statale e il contributo dele Historiae di Leonardo Bruni. In: Leonardo Bruni cancelliere della Repubblica di Firenze. Firenze: Leo Olshki, 1990.

FUBINI, Ricardo. Storiografia dell'Umanesimo in Italia da Leonardo Bruni ad Annio da Viterbo. [S.I.]: Storia e letteratura, 2003.

GARIN, Eugênio (ed.). Prosatori Latini del Quattrocento. Torino: Einaudi, 1976.

GARIN, Eugênio. Ciência e Vida Civil no Renascimento Italiano. São Paulo: Ed. UNESP, 1996.

GARIN, Eugênio. Italian Humanism. Westport: Greenwood Press, 1975 [1965].

GARIN, Eugênio. La citè idéale de la Renaissance Italienne. In: Les utopies à la Renaissance. Bruxelles: Presses Universitaires de Bruxelles, 1963.

GRIFFITHS, G; Hankins, J.; THOMPSON, D. The Humanism of Leonardo Bruni. Binghamton; New York: Center for Medieval and Early Renaissance Studies, 1987.

HANKINS, James (org.). Renaissance Civic Humanism: reappraisals and reflections. Cambridge: Cambridge University Press, 2000.

HANKINS, James. Coluccio Salutati e Leonardo Bruni. In: CILIBERTO, M. (org.). Enciclopedia Italiana. Ottava appendice. Il contributo italiano alla storia del pensiero. Roma: Filosofia, 2012.

HANKINS, James. Plato in the Italian Renaissance. Leiden: [s.n.], 1990, v. I.

HANKINS, James. Rhetoric, history and ideology: the civic panegyrics of Leonardo Bruni. In: Renaissance Civic Humanism. Cambridge University Press, 2000.

HANKINS, James. The 'Baron Thesis' after Forty Years and Some Recent Studies of Leonardo Bruni. Journal of the History of Ideas, v. 56, n. 2, p. 309-338, 1995.

KLEIN, Francesca. Considerazioni sull'ideologia della città di Firenze tra Trecento e Quattrocento. Giovanni Villani - Leonardo Bruni. Richerche historiche, v. 10, p. 311-336, 1980.

KOHL, B. G; WITT, R. G. The Earthly Republic: Italian Humanists on Government and Society. Philadelphia: University of Pennsylvania Press, 1978.

LORAUX, N. L'Invention d'Athènes. Histoire de I'oraison funèbres dans la cité classique. Paris: Mouton; Éd. I'EHESS, 1981.

NAJEMY, John. Storia di Firenze, 1200-1575. Turin: Einaudi, 2014.

PERNOT, Laurent. La Rhétorique d'éloge dans le monde gréco-romain. Paris: Éd. Brepolis, 1993. 2 tomos.

PINTO, Fabrina M. A cidade ideal de Leonardo Bruni. Morus - Utopia e Renascimento, v. 10, p. 367-388, 2015.

PINTO, Fabrina M. O Elogio da cidade de Florença (Laudatio Florentinae Urbis), de Leonardo Bruni. Morus - Utopia e Renascimento, v. 11, n. 2, p. 243-335, 2016.

POLÍBIO. História. Brasília: Ed. UnB, 1985.

PRADELLE, Laurence Bernard. L'Influence de la Seconde Sophistique sur la Laudatio Florentinae urbis de Leonardo Bruni. Rhetorica: A Journal of the History of Rhetoric, v. 18, $\mathrm{n}$. 4, p. 355-387, 2000. 
PRADELLE, Laurence Bernard. Leonardo Bruni Aretino. Lettres Familières. Édition, traduction et notes de Laurence Pradelle. Presses Universitaires de la Méditerranée, 2014. 2 tomes.

REVEST, Clémence. Les enjeux de la transmission aux origines de I'humanisme: I'exemple de l'Éloge de la ville de Florence de Leonardo Bruni. Questes, 11, p. 7-16, 2007.

RUBINSTEIN, N. Florentine libertas. Rinascimento, s. II, p. 3-26, 1986.

RUBINSTEIN, N. Il Bruni a Firenze: retorica e politica. In: Leonardo Bruni cancelliere della repubblica di Firenze. Convegno di studi a cura di P. Viti. Firenze: [s.n.], 1990.

SALUTATI, Coluccio. Invective Against A. Loschi. In: BALDASSARI, S. Coluccio Salutati Political Writings. London: The I Tatti RenaissanceHarvard University Press, 2014.

SEIGEL, Jerrold E. "Civic humanism" or Ciceronian rhetoric? The culture of Petrarch and Bruni. Past \& Present, v. 34. n. 1, p. 3-48, 1966.

SKINNER, Quentin. Fundações do Pensamento político Moderno. São Paulo: Companhia das Letras, 1996.

STAUBLE, A. Due panegirici di città tra Medievo e Rinascimento. Bibliothèque d'Humanisme et Renaissance, n. 38, p. 157-164, 1976.

The Cambridge Companion to Renaissance Humanism (Cambridge Companions to Literature). Cambridge, UK: Cambridge University Press, 1996.

VASOLI. Bruni Leonardo. In: Dizionario biografico degli italiani. Tomo 14. Rome: Istituto dela Enciclopedia italiana, 1972.

VASOLI. Considerazioni sulla Laudatio Urbis Florentinae di Leonardo Bruni. In: Estrato dall'Annuario 1961-1962 del Liceo Ginnasio Statale F. Petrarca di Arezzo. Vol. XXXV I. Firenze: Istituto Nazionale di Studi sul Rinascimento, 1961-1962.

VASOLI. Considerazioni sulla Laudatio Urbis Florentinae di Leonardo Bruni. In: Estrato dall'Annuario 1961-1962 del Liceo Ginnasio Statale F. Petrarca di Arezzo. Vol. XXXV I. Firenze: Istituto Nazionale di Studi sul Rinascimento, [s.d.].

VITI, Paolo. Leonardo Bruni cancelliere della repubblica di Firenze. Convegno di studi a cura di P. Viti. Firenze: [s.n.], 1990.

VITI, Paolo. Leonardo Bruni e Firenze. Studi suite lettere pubbliche e private. Roma: Bulzoni, 1992.

VITI, Paolo. Opere letterarie e politiche di Leonardo Bruni. Torino: Unione Tipografico-Editrice Torinese, 1996.

WITT, G. Civic Humanism and the Rebirth of the Ciceronian Oration. Modern Language Quarterly, n. 51, p. 167-184, 1990. 